\title{
DYNAMIKA ZMIAN LICZBY OSÓB KORZYSTAJĄCYCH Z USŁUG NOCLEGOWYCH W HOTELACH W WOJEWÓDZTWIE PODKARPACKIM
}

\begin{abstract}
Celem pracy jest analiza dynamiki zmian liczby osób korzystających z usług noclegowych w hotelach w województwie podkarpackim w latach 2008-2015. Do oceny wykorzystano dane empiryczne z Głównego Urzędu Statystycznego ${ }^{2}$ oraz Urzędu Statystycznego w Rzeszowie ${ }^{3}$. Otrzymane dane dotyczące zmian liczby turystów, zarówno krajowych, jak i zagranicznych korzystających z usług noclegowych, poddano dokładnej analizie, w której wykorzystano metody oceny dynamiki procesów ekonomicznych zarówno w skali bezwzględnej jak i względnej (procentowej). Wyniki w skali względnej dają lepszy obraz dynamiki zmian procesów ekonomicznych, gdyż wartości uzyskują wspólną wartość początkową równą $100 \%$. Zwrócono uwagę nie tylko na zmiany procentowe badanych procesów, ale również na szybkości i przyspieszenia tych zmian. Zatem wyniki informują, z jaką dynamiką wzrasta liczba każdych 100 początkowych osób korzystających z usług hotelarskich w województwie podkarpackim w latach 2008-2015. Porównując dynamikę procesów dla wartości skokowych i ciągłych, zarówno w skali bezwzględnej, jak i względnej dla turystów polskich oraz zagranicznych, zaobserwowano ogólny trend wzrostowy dla obu przypadków, pomimo niewielkiego załamania w latach 2011-2012. Zauważono również w badanych latach, że dynamika wzrostu liczby turystów zagranicznych korzystających z usług w hotelach jest nieco większa, niż turystów krajowych, chociaż całkowite wartości przedstawiają całkowicie odwrotny obraz. Świadczy to o coraz większym zainteresowaniu turystów zagranicznych podkarpackim rynkiem turystycznym, pomimo, iż ich udział w ogólnej liczbie jest nadal stosunkowo niski.
\end{abstract}

Słowa kluczowe: zarządzanie w hotelarstwie, dynamika zmian, hotele, usługi noclegowe, turystyka.

\section{OGÓLNA CHARAKTERYSTYKA BAZY NOCLEGOWEJ W WOJEWÓDZTWIE PODKARPACKIM}

Turystyka na Podkarpaciu odgrywa w ostatnich latach znaczącą rolę. Sektor ten przynosi oprócz wielu korzyści ekonomicznych również korzyści społeczne. Termin „turysty-

${ }^{1}$ Paweł Łuka, doktor nauk ekonomicznych, Zakład Gospodarki Turystycznej, Katedra Turystyki i Rekreacji, Wydział Wychowania Fizycznego, Uniwersytet Rzeszowski; e-mail: pluka@ur.edu.pl.

${ }^{2}$ Główny Urząd Statystyczny. Departament Badań Społecznych i Warunków Życia. Informacje i opracowania statystyczne. Turystyka w 2015 roku, Zakład Wydawnictw Statystycznych. Warszawa 2016.

${ }^{3}$ Urząd Statystyczny w Rzeszowie. Ośrodek Statystyki Sportu i Turystyki oraz Podkarpacki Ośrodek Badań Regionalnych. Informacje i opracowania statystyczne. Turystyka w województwie podkarpackim w latach 2014 i 2015 . Rzeszów 2016. 
ka" w tym kontekście rozumiany jest tutaj bardzo szeroko i dotyczy różnego rodzaju wydatków oraz dochodów związanych z wyjazdami i przyjazdami odwiedzających.

Województwo podkarpackie posiada wiele wyjątkowych walorów przyrodniczych oraz zabytków kultury. Atrakcje oraz inne potencjalne zasoby turystyczne stwarzają idealne warunki do rozwoju turystyki. Rozwojowi ruchu turystycznego sprzyja również położenie regionu u zbiegu granic trzech państw: Polski, Ukrainy i Słowacji oraz dobra infrastruktura transportowa. Ponadto jest najmniej zurbanizowanym województwem w kraju, gdyż tylko 41,3\% ludności mieszka w miastach. Ważnym czynnikiem jest również fakt, iż Podkarpacie należy do najczystszych ekologicznie regionów Polski.

Podstawowym elementem gospodarki turystycznej województwa jest baza noclegowa i jej wykorzystanie, będące miernikiem konsumpcji produktów turystycznych. Za pomocą liczby turystycznych obiektów i miejsc noclegowych oferowanych turystom mierzy się najczęściej potencjał turystyczny regionu, a poprzez liczbę korzystających, liczbę udzielonych noclegów czy średnią długość pobytu turystów w obiektach wykorzystanie tego potencjału. W niniejszym badaniu skupiono się na liczbie turystycznych obiektów noclegowych, miejscach noclegowych oraz na turystach krajowych i zagranicznych, korzystających z bazy hotelowej w województwie podkarpackim ${ }^{4}$.

W dniu 31 lipca 2015 roku w województwie podkarpackim zarejestrowanych było 527 turystycznych obiektów noclegowych. Całkowita baza noclegowa dotyczyła 18 rodzajów obiektów zbiorowego zakwaterowania, z których 208 to obiekty hotelowe, a 319 to pozostałe obiekty noclegowe. Wśród obiektów hotelowych najliczniejszą grupę stanowiły hotele, posiadające łącznie 135 obiektów, a wśród pozostałych obiektów noclegowych najwięcej, było kwater agroturystycznych -67 . Z ogólnej liczby obiektów 400 było placówkami całorocznymi, co stanowiło prawie $76 \%$ wszystkich oferowanych obiektów. W porównaniu z rokiem 2014 liczba obiektów wzrosła o $14(2,7 \%)$, w tym hoteli o $5(3,8 \%)^{5}$.

We wszystkich turystycznych obiektach noclegowych w ofercie było 28,7 tys. miejsc noclegowych, co stanowiło $4 \%$ ogółu miejsc noclegowych w kraju. W porównaniu z 2014 r. liczba miejsc noclegowych wzrosła o 1,1 tys. (4\%). Miejsca całoroczne stanowiły aż $83 \%$ wszystkich miejsc noclegowych (23,7 tys.). Tradycyjnie najwięcej miejsc noclegowych oferowały hotele $-9,4$ tys. miejsc, co stanowiło 32,6\% ogólnej liczby dostępnych miejsc noclegowych według stanu w dniu 31 lipca 2015 roku. Ponadto w roku 2015 w porównaniu do roku 2014 liczby wszystkich obiektów oraz miejsc noclegowych wzrosły odpowiednio o $2,0 \%$ i $1,6 \%$.

\footnotetext{
${ }^{4}$ Z. Kruczek, G. Wolak, Baza noclegowa $w$ turystyce [w:] Obstuga ruchu turystycznego, red. Z. Kruczek, Kraków 2012, s. 73-112; E. Świstak, B. Sawicka, M. Świątkowska, Baza noclegowa jako czynnik rozwoju turystyki w województwie warmińsko-mazurskim. Studia i Materiały CEPL w Rogowie, R. 15. z. 37/4/2013. 2013, s. 313-320.

${ }^{5}$ Główny Urząd Statystyczny. Departament Badań Społecznych i Warunków Życia. Informacje i opracowania statystyczne. Turystyka w 2015 roku, Zakład Wydawnictw Statystycznych, Warszawa 2016. Urząd Statystyczny w Rzeszowie. Ośrodek Statystyki Sportu i Turystyki oraz Podkarpacki Ośrodek Badań Regionalnych. Informacje i opracowania statystyczne. Turystyka w województwie podkarpackim w latach 2014 i 2015, Rzeszów 2016.

${ }^{6}$ Główny Urząd Statystyczny. Departament Badań Społecznych i Warunków Życia. Informacje i opracowania statystyczne. Turystyka w 2015 roku, Zakład Wydawnictw Statystycznych, Warszawa 2016; Urząd Statystyczny w Rzeszowie. Ośrodek Statystyki Sportu i Turystyki oraz Pod-
} 
W 2015 r. obiekty zlokalizowane na terenie województwa stanowiły 5,3\% wszystkich działających w kraju, przy powierzchni województwa stanowiącej 5,7\% powierzchni kraju i liczbie ludności stanowiącej 5,5\% ludności Polski. Pod względem liczby obiektów przypadających na $\mathrm{km}^{2}$, województwo podkarpackie zajmowało 6. miejsce w kraju ze wskaźnikiem gęstości równym 0,02953, co oznacza, że przeciętnie na $100 \mathrm{~km}^{2}$ zlokalizowane były trzy turystyczne obiekty noclegowe. Wskaźnik gęstości bazy noclegowej, mierzony liczbą miejsc noclegowych przypadających na $1 \mathrm{~km}^{2}$ powierzchni województwa w 2015 r. wyniósł 1,6 i nieznacznie wzrósł w porównaniu z rokiem poprzednim. Średnia dla kraju wyniosła 2,3.

Tabela 1. Liczba hoteli w województwie podkarpackim według kategorii w latach 2008-2015

\begin{tabular}{|l|c|c|c|c|c|c|c|c|}
\hline Wyszczególnienie & $\mathbf{2 0 0 8}$ & $\mathbf{2 0 0 9}$ & $\mathbf{2 0 1 0}$ & $\mathbf{2 0 1 1}$ & $\mathbf{2 0 1 2}$ & $\mathbf{2 0 1 3}$ & $\mathbf{2 0 1 4}$ & $\mathbf{2 0 1 5}$ \\
\hline Hotele ogółem & 68 & 74 & 84 & 88 & 105 & 117 & 130 & 135 \\
\hline$* * * * *$ & -- & -- & -- & -- & -- & 1 & 1 & 1 \\
\hline$* * * *$ & 1 & 1 & 2 & 2 & 6 & 8 & 11 & 12 \\
\hline$* * *$ & 30 & 37 & 41 & 44 & 53 & 53 & 63 & 62 \\
\hline$* *$ & 25 & 26 & 27 & 27 & 36 & 40 & 40 & 41 \\
\hline$*$ & 10 & 7 & 8 & 7 & 6 & 9 & 7 & 9 \\
\hline $\begin{array}{l}\text { Hotele w trakcie } \\
\text { kategoryzacji }\end{array}$ & 2 & 3 & 6 & 8 & 4 & 6 & 8 & 10 \\
\hline
\end{tabular}

Źródło: opracowanie własne na podstawie danych z GUS.

Tabela 2. Liczba miejsc noclegowych w hotelach w województwie podkarpackim według kategorii w latach 2008-2015

\begin{tabular}{|l|r|r|r|r|r|r|r|r|}
\hline Wyszczególnienie & $\mathbf{2 0 0 8}$ & $\mathbf{2 0 0 9}$ & $\mathbf{2 0 1 0}$ & $\mathbf{2 0 1 1}$ & $\mathbf{2 0 1 2}$ & $\mathbf{2 0 1 3}$ & $\mathbf{2 0 1 4}$ & $\mathbf{2 0 1 5}$ \\
\hline Hotele ogółem & 4094 & 4503 & 4863 & 5119 & 6093 & 6843 & 8715 & 9368 \\
\hline$* * * * *$ & -- & -- & -- & -- & -- & 39 & 142 & 146 \\
\hline$* * * *$ & 112 & 112 & 154 & 151 & 492 & 833 & 1899 & 2106 \\
\hline$* * *$ & 2138 & 2643 & 2903 & 3131 & 3611 & 3739 & 4419 & 4486 \\
\hline$* *$ & 1232 & 1272 & 1168 & 1147 & 1603 & 1612 & 1625 & 1836 \\
\hline$*$ & 482 & 315 & 336 & 295 & 268 & 347 & 274 & 334 \\
\hline $\begin{array}{l}\text { Hotele w trakcie } \\
\text { kategoryzacji }\end{array}$ & 130 & 161 & 302 & 395 & 119 & 273 & 356 & 460 \\
\hline
\end{tabular}

Źródło: opracowanie własne na podstawie danych GUS.

W tabelach 1 i 2 przedstawiono hotele w województwie podkarpackim według kategorii z uwzględnieniem liczby obiektów oraz liczby miejsc noclegowych w latach 2008-2015. W badanym okresie zaobserwowano ogólny wzrost wszystkich hoteli w woje-

karpacki Ośrodek Badań Regionalnych. Informacje i opracowania statystyczne. Turystyka w województwie podkarpackim w latach 2014 i 2015, Rzeszów 2016. 
wództwie podkarpackim (wzrost o 67 jednostek), jednak od roku 2011 wzrost ten był najbardziej dynamiczny. W przypadku miejsc noclegowych w hotelach, również nastąpił ogólny wzrost wartości w badanym okresie i w podobny sposób jak w przypadku wzrostu liczby obiektów, wzrost ten był najbardziej dynamiczny od roku 2011. Główny wpływ na to zjawisko miał wzrost hoteli 3- i 4-gwiazdkowych. W 2015 r., podobnie jak w latach poprzednich, w strukturze dominowały hotele 3-gwiazdkowe (62) oraz 2-gwiazdkowe (41) stanowiące odpowiednio $46 \%$ i $30 \%$ obiektów tego rodzaju w województwie. Pierwszy w województwie hotel 4-gwiazdkowy rozpoczął działalność w 2008 r., a w 2015 r. było ich już 12 .

Pierwszy hotel 5-gwiazdkowy pojawił się w 2013 r. Hotele w województwie są średniej wielkości, przeciętnie dysponują 34 pokojami oraz 69 miejscami. Analogiczne wskaźniki dla kraju wynoszą odpowiednio 51 i 102. Ponadto, wśród hoteli ogółem, oprócz hoteli utrzymujących się w swoich kategoriach, pewna ich liczba pozostawała w trakcie kategoryzacji. W 2015 roku w porównaniu do roku 2008 liczba wszystkich obiektów hotelowych i miejsc noclegowych w tych hotelach wzrastała odpowiednio o 98,5\% i 128,8\%, natomiast w 2015 roku w porównaniu do roku 2014 wzrosty te wynosiły odpowiednio - 3,9\% dla liczby obiektów hotelowych oraz 7,5\% dla liczby miejsc noclegowych w tych hotelach ${ }^{7}$.

\section{MATERIAŁ I METODY BADAŃ}

Celem analizy jest ocena dynamiki zmian liczby turystów korzystających z usług noclegowych w hotelach w województwie podkarpackim w latach 2008-2015. W badaniu uwzględniono podział na turystów krajowych i turystów zagranicznych. W przeprowadzonej analizie wykorzystano dane empiryczne opublikowane w Głównym Urzędzie Statystycznym $^{8}$ oraz Urzędzie Statystycznym w Rzeszowie ${ }^{9}$. Dotyczą one liczby turystów krajowych i zagranicznych korzystających z hoteli na Podkarpaciu w latach 2008-2015.

$\mathrm{W}$ badaniach skorzystano $\mathrm{z}$ opracowań przedstawionych $\mathrm{w}$ literaturze na temat oceny dynamiki zmian procesów ekonomicznych ${ }^{10}$.

${ }^{7}$ Urząd Statystyczny w Rzeszowie. Ośrodek Statystyki Sportu i Turystyki oraz Podkarpacki Ośrodek Badań Regionalnych. Informacje i opracowania statystyczne. Turystyka w województwie podkarpackim w latach 2014 i 2015, Rzeszów 2016.

${ }^{8}$ Główny Urząd Statystyczny. Departament Badań Społecznych i Warunków Życia. Informacje i opracowania statystyczne, Turystyka w 2015 roku, Zakład Wydawnictw Statystycznych, Warszawa 2016.

9 Urząd Statystyczny w Rzeszowie. Ośrodek Statystyki Sportu i Turystyki oraz Podkarpacki Ośrodek Badań Regionalnych. Informacje i opracowania statystyczne. Turystyka w województwie podkarpackim w latach 2014 i 2015, Rzeszów 2016.

${ }^{10} \mathrm{~K}$. Stokłosa, Krytyka wspótczesnych metod oceny i porównań dynamiki procesów ekonomicznych. Materiaty Konferencji Naukowej Politechniki Radomskiej, Radom 2004; K. Stokłosa, Krytyka wspótczesnych metod oceny dynamiki procesów w ekonomii $i$ w zarządzaniu, red. nauk. M. Trocki i S. Gregorczyk, Warszawa 2006; P. Łuka, Dynamika wzrostu liczby osób korzystających $z$ krajowych potaczeń lotniczych $w$ Polsce $w$ latach 2002-2005, Ekonomia i Nauki Humanistyczne, z. 16, Zeszyty Naukowe Politechniki Rzeszowskiej nr 235, Rzeszów 2007, s. 51-59; P. Łuka, K. Kwiatkowska-Sienkiewicz, Kinetic analysis of quality, utility and price changes of the secondhand cars in Poland, Annals of the Ovidius University, Economic Science Series, Vol. X, Issue 1, 2010, s. 1219-1223; P. Łuka, K. Kwiatkowska-Sienkiewicz, Quality and utility estimation 
Symbole wykorzystane w pracy:

$t \quad$ - czas wyrażony w jego jednostkach, np. [l] - rok;

$J_{t}$ - ogólny symbol wartości miary w czasie $t$, wyrażonej w skali bezwzględnej, w szeregach czasowych uznanych za skokowe (np. liczba turystów ogółem korzystających z usług hotelarskich w roku $t$ );

$J_{0} \quad$ - początkowa wartość miary w czasie $t$ (wartość z roku 2008), wyrażonej w skali bezwzględnej, w szeregach czasowych uznanych za skokowe, dla $t=0$;

$J_{k}$ - końcowa wartość miary w czasie $t$ (wartość z roku 2015), wyrażonej w skali bezwzględnej, w szeregach czasowych uznanych za skokowe;

$M_{t}$ - ogólny symbol wartości miary w czasie $t$, wyrażonej w skali bezwzględnej, w szeregach czasowych uznanych za ciągłe (np. liczba turystów ogółem korzystających $\mathrm{z}$ usług hotelarskich $\mathrm{w}$ roku $t$ );

$M_{0}$ - początkowa wartość miary w czasie $t$ (wartość z roku 2008), w szeregach czasowych uznanych za ciągłe, dla $t=0$;

$M_{k}$ - końcowa wartość miary w czasie $t$ (wartość z roku 2015), w szeregach czasowych uznanych za ciągłe;

$P_{t} \quad$ - wartości miary w czasie $t$ wyrażone w skali względnej, gdzie $P_{0}=100 \%$,

$P_{J t}$ - wartość miary w czasie $t$ wyrażona w skali względnej, gdzie $P_{0}=100 \%$, wartości procentowe otrzymywane są w drodze liniowej transformacji wartości $J_{t}$; szereg $P_{J t}$ informuje o wzroście lub spadku 100 początkowych jednostek wartości miary w czasie biegu procesu; jest to skala unormowana;

$P_{M t}$ - wartość miary w czasie $t$ wyrażona w skali względnej, gdzie $P_{0}=100 \%$, wartości procentowe otrzymywane są w drodze liniowej transformacji wartości $M_{i}$; szereg $P_{M t}$ informuje o wzroście lub spadku 100 początkowych jednostek wartości miary w czasie biegu procesu; jest to skala unormowana;

$P_{0}$ - początkowa wartość miary w czasie $t$ (wartość $\mathrm{z}$ roku 2008), wyrażona w skali względnej (procentowej), $P_{0}=100 \%$;

$P_{k}$ - końcowa wartość miary w czasie $t$ (wartość z roku 2015), wyrażona w skali względnej (procentowej);

$P_{K}$ - względna (procentowa) zmiana końcowej wartości miary szeregu czasowego w stosunku do wartości miary początkowej (np. $M_{k}$ do $M_{0}$, gdzie $M_{0}=100 \%$ ).

W tabeli 3 przedstawiono dane empiryczne liczby turystów korzystających z usług noclegowych w hotelach w województwie podkarpackim w latach 2008-2015, z uwzględnieniem całkowitej liczby turystów, jak również turystów polskich i turystów zagranicznych. Uzyskane pierwotne dane empiryczne oznaczono zbiorem $J_{t}$, gdzie $t$ jest to czas podany w latach od 2008 do 2015. Mają one charakter skokowy (dyskretny). Aby można było dokonać prawidłowej oceny dynamiki zmian ${ }^{11}$, transformowano je do szeregów czasowych ciągłych $M_{t}$, poprzez sumowanie kolejnych zbiorów według równania (1):

$$
M_{t}=\sum_{t=0}^{t} J_{t}, \text { oraz } J_{t}=M_{t}-M_{t-1}
$$

of the second-hand cars, Current trends in commodity science. Selected quality problems, Zeszyty Naukowe UE w Poznaniu nr 160, Poznań 2010, s. 144-153.

${ }^{11}$ K. Stokłosa, Krytyka wspótczesnych metod oceny i porównań...; K. Stokłosa, Krytyka wspótczesnych metod oceny dynamiki procesów...; P. Łuka, Dynamika wzrostu liczby osób..., s. 51-59. 
Tabela 3. Liczba turystów korzystających $\mathrm{z}$ usług hotelowych w województwie podkarpackim w latach 2008-2015 z podziałem na turystów polskich i turystów zagranicznych

\begin{tabular}{|l|c|c|c|}
\hline Rok & Turyści ogółem & Turyści polscy & Turyści zagraniczni \\
\hline $\mathbf{2 0 0 8}$ & 229454 & 191943 & 37511 \\
\hline $\mathbf{2 0 0 9}$ & 263988 & 219346 & 44642 \\
\hline $\mathbf{2 0 1 0}$ & 294756 & 245044 & 49712 \\
\hline $\mathbf{2 0 1 1}$ & 323200 & 271672 & 51528 \\
\hline $\mathbf{2 0 1 2}$ & 353915 & 295332 & 58583 \\
\hline $\mathbf{2 0 1 3}$ & 417953 & 340888 & 77065 \\
\hline $\mathbf{2 0 1 4}$ & 532537 & 442709 & 89828 \\
\hline $\mathbf{2 0 1 5}$ & 575470 & 479422 & 96048 \\
\hline
\end{tabular}

Źródło: opracowanie własne na podstawie danych z GUS (2016).

Wartości $M_{t}$ informują, ile łącznie turystów, zarówno ogółem, jak i krajowych lub zagranicznych, skorzystało z usług noclegowych w hotelach w województwie podkarpackim po upływie czasu $t$. Zatem zbiory $M_{t}$ stanowią obraz zmian liczby turystów korzystających z usług noclegowych w skali wieloletniej. Umożliwiają one ocenę dynamiki zmian badanych procesów w skali bezwzględnej dla poszczególnych lat. Aby uzyskać możliwość oceny dynamiki również w skali względnej zbiory $M_{t}$ transformowano liniowo do skali względnej (procentowej) $P_{M t}[\%]$, według równania (2):

$$
P_{M t}=\frac{M_{t} \cdot 100}{M_{0}}[\%]
$$

gdzie: $P_{0}=100 \%$,

$$
M_{0}>0 \text {, }
$$

$M_{0}$ - wartość początkowa zbioru,

$M_{t}$ - wartość miary w czasie $t$.

W skali $P_{M t}$ wszystkie badane zbiory uzyskują wspólną wartość początkową $P_{0}=100 \%$. Analogicznie zbiory skokowe $J_{t}$ transformowano do skali procentowej $P_{J t}[\%]$, według wzoru (3):

$$
P_{J t}=\frac{J_{t} \cdot 100}{J_{0}}[\%]
$$

gdzie: $P_{0}=100 \%$,

$$
J_{0}>0
$$

$J_{0}$ - wartość początkowa zbioru,

$J_{t}$ - wartość miary w czasie $t$.

Szeregi $P_{t}$ umożliwiają najdokładniejsze porównywanie dynamik. Informują one, z jaką dynamiką wzrasta liczba każdych 100 początkowych turystów korzystających 
z usług noclegowych w hotelach w województwie podkarpackim w latach 2008-2015. W porównaniach dynamik niezbędne jest uwzględnienie takiej samej wartości początkowej porównywanych procesów, a właśnie to zapewnia skala względna (procentowa) $P_{t}^{12}$.

W niniejszej pracy przyjęto dwie definicje dynamiki, mianowicie bezwzględną dla szeregów $M_{t}$ i względną (właściwą) dla szeregów $P_{t}$. Dynamika bezwzględna to zmiany szybkości chwilowej i przyspieszenia chwilowego na ściśle określonej drodze przebiegu procesu. Dynamika względna właściwa, to zmiany szybkości chwilowej właściwej i przyspieszenia chwilowego właściwego na ściśle określonej drodze przebiegu procesu. Przez drogę przebiegu danego procesu rozumie się mechanizm elementarnego zdarzenia, powtarzany wielokrotnie w czasie, w tym w efekcie przyczynowo-skutkową funkcję opisującą, uwzględniającą istotnie mechanizm elementarny ${ }^{13}$.

Wszystkie zbiory $J_{t}$, otrzymane zbiory $M_{t}$ oraz obliczone zbiory wartości procentowych $P_{t}$ zarówno dla zbiorów skokowych jak i ciągłych przedstawiono w tabeli 4, w której podano również wartości wprowadzonego parametru $P_{K}$ [\%], obliczonego według wzorów (4), (5) i (6):

- dla zbiorów skokowych $J_{t}$ :

$$
P_{K}=\frac{J_{k} \cdot 100}{J_{0}}[\%]
$$

gdzie: $J_{0}>0$,

$J_{p}$ - początkowa wartość danej miary,

$J_{k}$ - końcowa wartość danej miary;

- dla zbiorów ciągłych $M_{t}$ :

$$
P_{K}=\frac{M_{k} \cdot 100}{M_{0}}[\%]
$$

gdzie: $M_{0}>0$,

$M_{p}$ - początkowa wartość danej miary,

$M_{k}$ - końcowa wartość danej miary;

- dla zbiorów skokowych i ciągłych $P_{t}$ :

$$
P_{K}=\frac{P_{k} \cdot 100}{P_{0}}[\%]
$$

gdzie: $P_{0}>0$

$P_{0}$ - początkowa wartość danej miary,

$P_{k}-$ końcowa wartość danej miary.

${ }^{12}$ K. Stokłosa, Krytyka wspótczesnych metod oceny i porównań dynamiki procesów ekonomicznych. Materiaty Konferencji Naukowej Politechniki Radomskiej, Radom 2004; K. Stokłosa, Krytyka wspótczesnych metod oceny dynamiki procesów...

${ }^{13}$ G. Abraham-Frois, Dynamique Economique, 9 édition. Précis-Dalloz, Paris 2002; E. Kondratowicz-Pietruszka, K. Stokłosa, Wybrane zagadnienia kinetyki procesów ekonomicznych, Kraków 1994. 
Wartość $P_{K}$ informuje, jaki procent stanowi końcowa wartość miary w porównaniu do miary początkowej, uznanej za równą $100 \%$. Wartości $P_{K}$ nie nadają się do oceny dynamiki procesów, dostarczają jednak interesujących informacji o zmianach wartości miary w końcowym etapie badanego procesu w stosunku do wartości początkowej tego pro$\mathrm{cesu}^{14}$.

Wyniki przedstawionych powyżej operacji zostały przedstawione w tabelach 4 i 5.

\section{WYNIKI OBLICZEŃ I WNIOSKI}

W tabeli 4 umieszczono skokowe (dyskretne) dane empiryczne dotyczące liczby turystów ogółem korzystających z usług w hotelach w województwie podkarpackim w latach 2008-2015 i oznaczono je umownie symbolem $J_{t}$. Przedstawiono w niej również wartości tego procesu, transformowane liniowo do zbiorów uznanych za ciągłe i oznaczono je symbolem $M_{t}$. Ponadto w tabeli tej umieszczono również względne (procentowe) wartości miary $P_{t}$ zarówno dla zbiorów skokowych $J_{t}$ jak i zbiorów ciągłych $M_{t}$. Dodatkowo dla każdego zbioru w skali bezwzględnej i względnej podano obliczone wartości zmian wartości końcowych do wartości początkowych $P_{K}$. Na podstawie danych umieszczonych w tabeli 4 sporządzono wykresy 1 i 2, na których przedstawiono liczbę turystów ogółem korzystających z usług w hotelach w województwie podkarpackim w latach 2008-2015 (wartości $J_{t}$ ). oraz dynamikę zmian ogólnej liczby turystów korzystających z usług w hotelach w województwie podkarpackim w tych latach (wartości $M_{t}$ ).

Ogólna liczba turystów korzystających z usług hotelowych w województwie podkarpackim w latach 2008-2015 narastała wraz z upływem czasu, czyli występował ogólny wzrost wartości miary. Proces ten był rozwojowy ze słabo rosnąca dynamiką. W latach 2008-2011 zaobserwowano spadek szybkości procesu, natomiast w latach 2011-2014 szybkość procesu wyraźnie rosła. Następnie, od 2014 do 2015 roku szybkość procesu bardzo wyraźnie spadała (tabela 4, wykresy 1 i 2 ).

Tabela 4. Liczba turystów ogółem korzystających z usług noclegowych w hotelach w województwie podkarpackim w latach 2008-2015

\begin{tabular}{|c|c|r|r|r|r|}
\hline Rok & $\boldsymbol{t}$ & $\boldsymbol{J}_{\boldsymbol{t}}$ & $\boldsymbol{P}_{\boldsymbol{J} \boldsymbol{t}}[\boldsymbol{\%}]$ & $\boldsymbol{M}_{\boldsymbol{t}}$ & $\boldsymbol{P}_{\boldsymbol{M} \boldsymbol{t}}[\boldsymbol{\%}]$ \\
\hline $\mathbf{2 0 0 8}$ & 0 & 229454 & 100,0 & 229454 & 100,0 \\
\hline $\mathbf{2 0 0 9}$ & 1 & 263988 & 115,1 & 493442 & 215,1 \\
\hline $\mathbf{2 0 1 0}$ & 2 & 294756 & 128,5 & 788198 & 343,5 \\
\hline $\mathbf{2 0 1 1}$ & 3 & 323200 & 140,9 & 1111398 & 484,4 \\
\hline $\mathbf{2 0 1 2}$ & 4 & 353915 & 154,2 & 1465313 & 638,6 \\
\hline $\mathbf{2 0 1 3}$ & 5 & 417953 & 182,2 & 1883266 & 820,8 \\
\hline $\mathbf{2 0 1 4}$ & 6 & 532537 & 232,1 & 2415803 & 1052,8 \\
\hline $\mathbf{2 0 1 5}$ & 7 & 575470 & 250,8 & 2991273 & 1303,6 \\
\hline $\boldsymbol{P}_{\boldsymbol{K}}[\boldsymbol{\%}]$ & & $\mathbf{2 5 0 , 8}$ & $\mathbf{2 5 0 , 8}$ & $\mathbf{1 3 0 3 , 6}$ & $\mathbf{1 3 0 3 , 6}$ \\
\hline
\end{tabular}

Źródło: opracowanie własne na podstawie danych z GUS (2016).

${ }^{14}$ E. Kondratowicz-Pietruszka, K. Stokłosa, Wybrane zagadnienia kinetyki procesów ekonomicznych, Kraków 1994; P. Łuka, M. Łuka, Analiza działalności hotelarskiej w Polsce w latach 1994-1999. Ekonomia i Nauki Humanistyczne z. 11. Zeszyty Naukowe Politechniki Rzeszowskiej Nr 201. Rzeszów 2002. s. 137-146.. 
Porównując graficznie zbiory skokowe (dyskretne) $-J_{t}$ i zbiory ciągłe $M_{t}$ dotyczące liczby turystów korzystających z usług noclegowych w hotelach w województwie podkarpackim w latach 2008-2015, zauważono, że obraz procesu ciągłego dokładniej przedstawia trend w czasie.

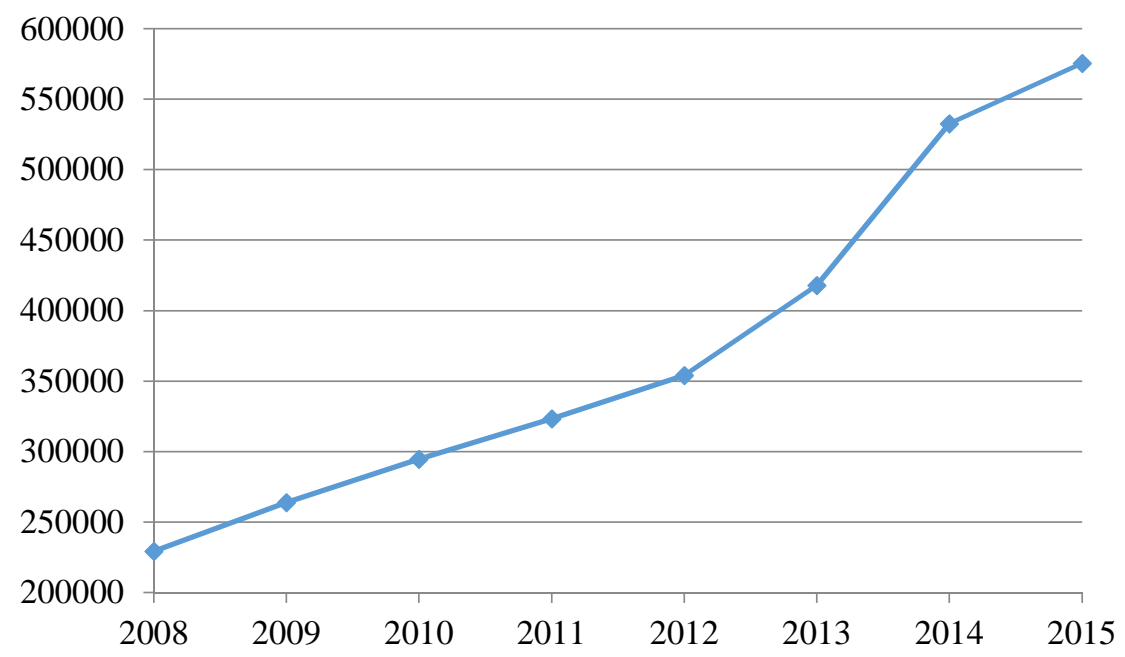

Wykres 1. Liczba turystów ogółem korzystających z usług noclegowych w hotelach w województwie podkarpackim w latach 2008-2015 - wartości $J_{t}$

Źródło: opracowanie własne na podstawie danych z tabeli 4.

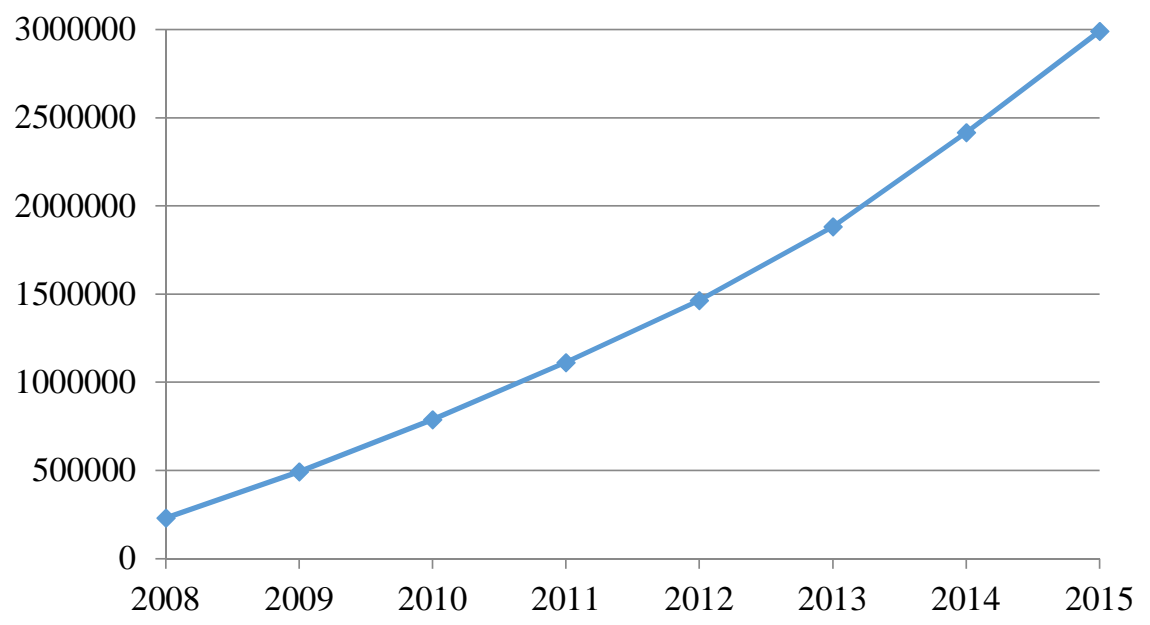

Wykres 2. Dynamika zmian ogólnej liczby turystów korzystających z usług noclegowych w hotelach w województwie podkarpackim w latach 2008-2015 - wartości $M_{t}$

Źródło: opracowanie własne na podstawie danych z tabeli 4. 
Tabela 5. Dynamika zmian liczby turystów korzystających z usług noclegowych w hotelach w województwie podkarpackim w latach 2008-2015 z podziałem na turystów polskich i turystów zagranicznych

\begin{tabular}{|c|c|c|c|c|c|c|c|c|c|}
\hline \multirow{3}{*}{ Rok } & \multirow{3}{*}{$t$} & \multicolumn{8}{|c|}{ Turyści korzystający z usług hotelarskich w województwie podkarpackim } \\
\hline & & & \multicolumn{3}{|c|}{ Turyści polscy } & \multicolumn{4}{|c|}{ Turyści zagraniczni } \\
\hline & & $J_{t}$ & $\begin{array}{c}P_{J t} \\
{[\%]}\end{array}$ & $M_{t}$ & $\begin{array}{l}P_{M t} \\
{[\%]}\end{array}$ & $J_{t}$ & $\begin{array}{c}P_{J t} \\
{[\%]}\end{array}$ & $M_{t}$ & $\begin{array}{l}P_{M t} \\
{[\%]}\end{array}$ \\
\hline 2008 & 0 & 191943 & 100,0 & 191943 & 100,0 & 37511 & 100,0 & 37511 & 100,0 \\
\hline 2009 & 1 & 219346 & 114,3 & 411289 & 214,3 & 44642 & 119,0 & 82153 & 219,0 \\
\hline 2010 & 2 & 245044 & 127,7 & 656333 & 341,9 & 49712 & 132,5 & 131865 & 351,5 \\
\hline 2011 & 3 & 271672 & 141,5 & 928005 & 483,5 & 51528 & 137,4 & 183393 & 488,9 \\
\hline 2012 & 4 & 295332 & 153,9 & 1223337 & 637,3 & 58583 & 156,2 & 241976 & 645,1 \\
\hline 2013 & 5 & 340888 & 177,6 & 1564225 & 814,9 & 77065 & 205,4 & 319041 & 850,5 \\
\hline 2014 & 6 & 442709 & 230,6 & 2006934 & 1045,6 & 89828 & 239,5 & 408869 & 1090,0 \\
\hline 2015 & 7 & 479422 & 249,8 & 2486356 & 1295,4 & 96048 & 256,1 & 504917 & 1346,1 \\
\hline$P_{K}[\%]$ & & 249,8 & 249,8 & 1295,4 & 1295,4 & 256,1 & 256,1 & 1346,1 & 1346,1 \\
\hline
\end{tabular}

Źródło: opracowanie własne na podstawie danych z GUS (2016).

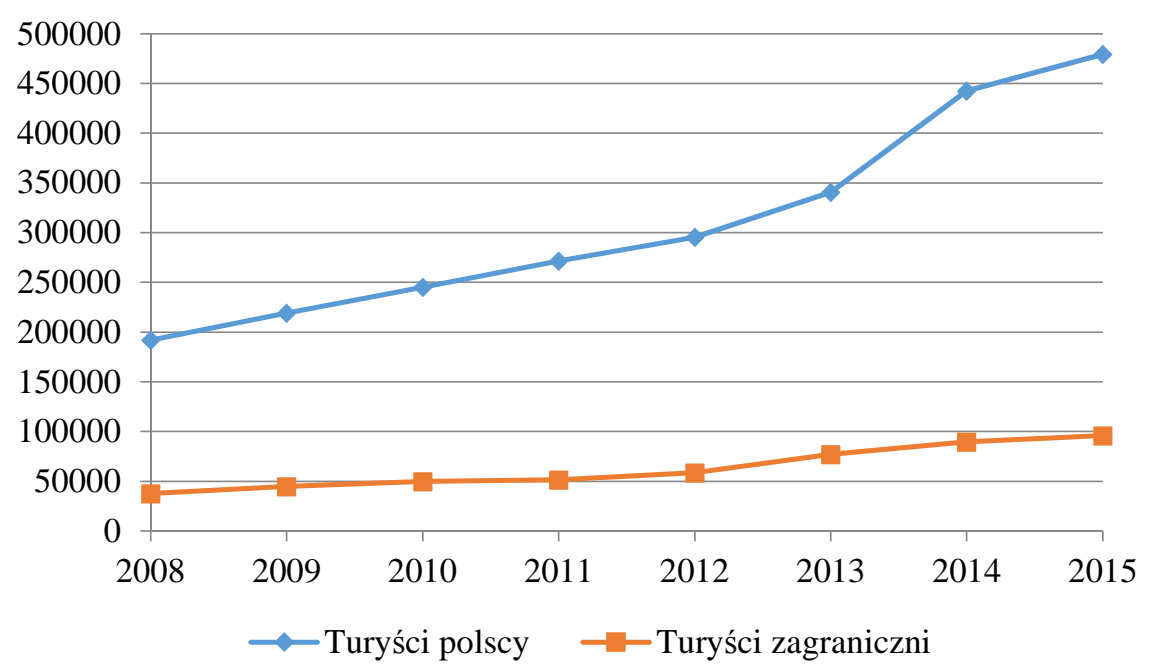

Wykres 3. Liczba turystów korzystających z usług noclegowych w hotelach w województwie podkarpackim w latach $2008-2015$ z podziałem na turystów polskich i turystów zagranicznych wartości $J_{t}$

Źródło: opracowanie własne na podstawie danych z tabeli 5. 


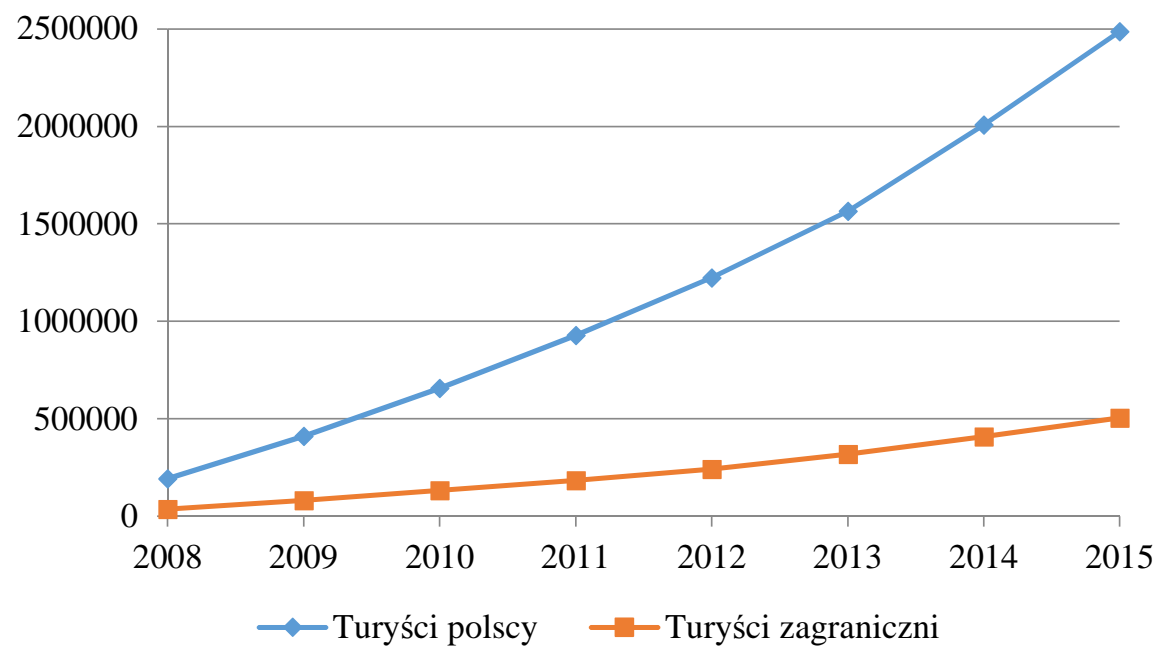

Wykres 4. Porównanie dynamiki zmian liczby turystów polskich i turystów zagranicznych korzystających z usług noclegowych w hotelach w województwie podkarpackim w latach 2008-2015 wartości $M_{t}$

Źródło: opracowanie własne na podstawie danych z tabeli 5.

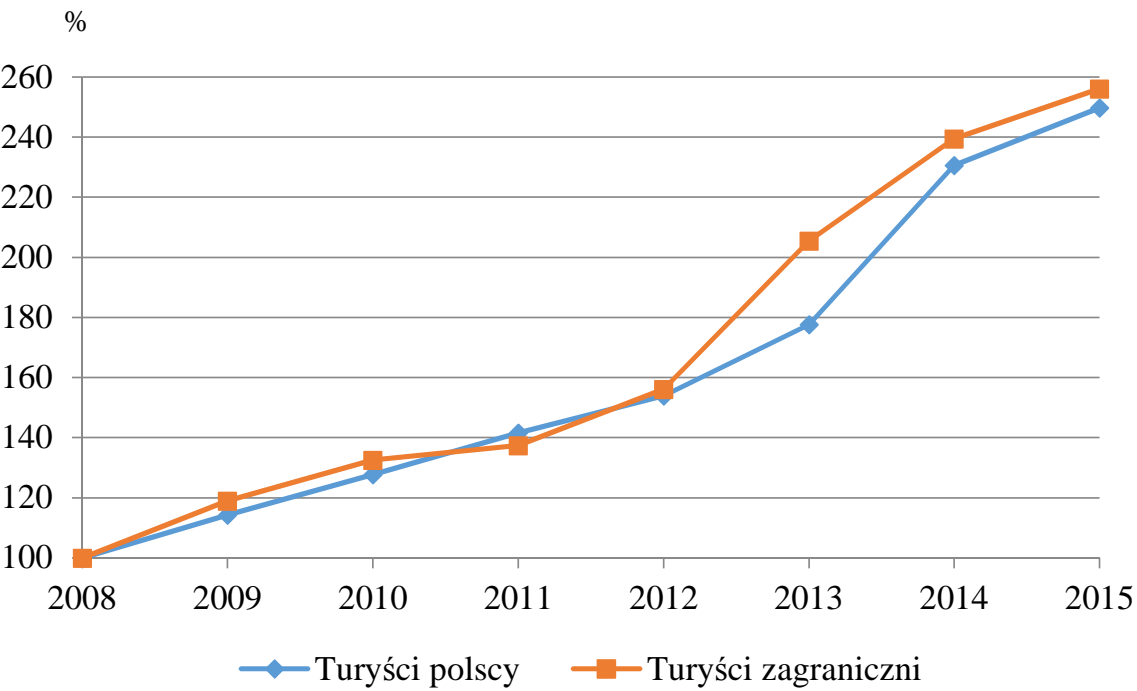

Wykres 5. Liczba turystów korzystających z usług noclegowych w hotelach w województwie podkarpackim w latach 2008-2015 z podziałem na turystów polskich i turystów zagranicznych dla zbiorów skokowych (dyskretnych) $J_{t}$ - wartości w skali $P_{J t}(\mathrm{w} \%)$

Źródło: opracowanie własne na podstawie danych z tabeli 5. 
$\%$

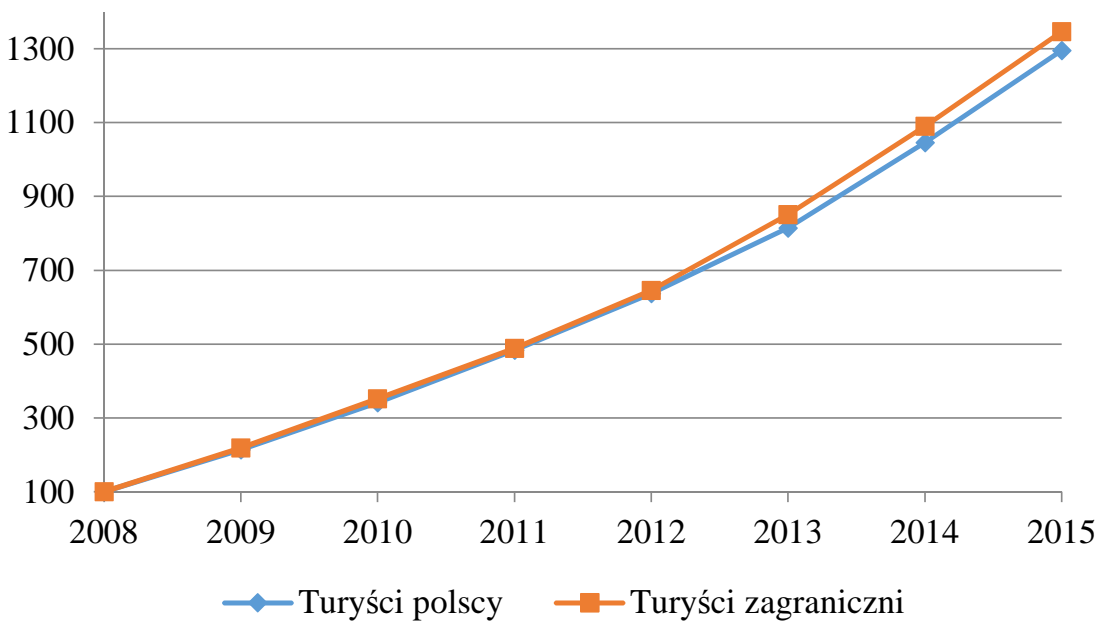

Wykres 6. Porównanie dynamiki zmian liczby turystów polskich i turystów zagranicznych korzystających z usług noclegowych w hotelach w województwie podkarpackim w latach 2008-2015 dla zbiorów ciągłych $M_{t}$ - wartości w skali $P_{M t}(\mathrm{w} \%)$

Źródło: opracowanie własne na podstawie danych z tabeli 5.

Na wykresie 3 przedstawiono liczbę turystów korzystających z usług noclegowych w hotelach w województwie podkarpackim w latach 2008-2015 z podziałem na turystów polskich oraz turystów zagranicznych. Wszystkie wartości podano w zbiorach skokowych (dyskretnych) $J_{t}$, w skali bezwzględnej. Wykres 4 przedstawia porównanie dynamiki zmian liczby turystów polskich i turystów zagranicznych w tym samym okresie. Wartości te podano w zbiorach $M_{t}$, uznanych za ciągłe, również w skali bezwzględnej. Z kolei na wykresach 5 i 6 przedstawiono te same zmiany dotyczące liczby turystów korzystających z usług w hotelach w województwie podkarpackim w latach 2008-2015 z podziałem na turystów polskich oraz turystów zagranicznych dla zbiorów skokowych i ciągłych, lecz w skali względnej (procentowej) $P_{t}$.

W latach 2008-2015 narastała liczba turystów krajowych i turystów zagranicznych korzystających $\mathrm{z}$ usług noclegowych w hotelach w województwie podkarpackim. W obydwu procesach zaobserwowano ogólny wzrost wartości miary $\left(P_{K}>100 \%\right)$. W przypadku turystów krajowych szybkość procesu narastała w latach 2008-2015, z tym, że nieco wolniej od roku 2014. Natomiast w przypadku turystów zagranicznych szybkość procesu narastała stopniowo w latach 2008-2015, lecz w roku 2011 zaobserwowano działanie czynników hamujących bieg procesu.

Analizując procesy ciągłe, zarówno w skali bezwzględnej $M_{t}$, jak i względnej (procentowej) $P_{t}$, widać dużą różnicę w dynamice wzrostu pomiędzy liczbą turystów krajowych $\left(P_{K}=1295,4 \%\right)$ a liczbą turystów zagranicznych $\left(P_{K}=1346,1 \%\right)$, na korzyść turystów zagranicznych (tabela 5 , wykresy 5 i 6 ). 


\section{ZAKOŃCZENIE I WNIOSKI}

Wartości w skali względnej (procentowej) $P_{t}$ umożliwiają najdokładniejsze porównywanie dynamiki procesów ekonomicznych. Informują one, $\mathrm{z}$ jaką dynamiką wzrasta liczba każdych 100 początkowych turystów korzystających z usług noclegowych w hotelach w województwie podkarpackim w latach 2008-2015. W porównaniu dynamiki niezbędne jest uwzględnienie takiej samej wartości początkowej porównywanych procesów, a właśnie to zapewnia skala względna (procentowa), gdyż wszystkie wartości w skali $P_{t}$ uzyskują wspólną wartość początkową $P_{0}=100 \%$.

Zbiory ciągłe, a w szczególności zbiory wyrażone w skali względnej (procentowej) pozwalają w dużo lepszy sposób dostrzec dynamikę procesu ekonomicznego. W badanym przypadku zbiory skokowe (dyskretne) $J_{t}$ transformowane do zbiorów ciągłych $M_{t}$ pokazują wyraźnie różnicę w dynamice wzrostu pomiędzy liczbą turystów krajowych a liczbą turystów zagranicznych korzystających z usług hotelarskich w województwie podkarpackim w latach 2008-2015.

Porównując dynamikę procesów dla wartości skokowych i ciągłych, zarówno w skali bezwzględnej, jak i względnej, zaobserwowano ogólny trend wzrostowy dla obu przypadków. Zauważono również w badanych latach, że dynamika wzrostu liczby turystów zagranicznych korzystających z usług noclegowych w hotelach jest nieco większa, niż turystów krajowych, chociaż całkowite wartości przedstawiają całkowicie odwrotną sytuację. Świadczy to o coraz większym zainteresowaniu turystów zagranicznych podkarpackim rynkiem turystycznym, pomimo iż ich udział w ogólnej liczbie jest nadal relatywnie niski i wynosi zaledwie $17 \%$.

Interesujący jest również fakt, że pomimo stosunkowo niskiego udziału turystów zagranicznych w całkowitej liczbie osób korzystających z usług hotelowych w województwie podkarpackim (przeciętnie 16,8\%) dynamika zmian turystów zagranicznych przedstawiona szczególnie za pomocą zbiorów ciągłych w skali względnej (procentowej) jest wyższa niż krajowych, pomimo że zbiory skokowe tego nie pokazują. Analizując rynek usług noclegowych w hotelach w województwie podkarpackim w latach 2008-2015 wskazać należy, że istnieje duże prawdopodobieństwo, iż pomimo dotychczasowego niskiego udziału w rynku, wzrost zagranicznych turystów korzystających z usług w hotelach $\mathrm{w}$ województwie podkarpackim będzie się utrzymywał. Jest to niewątpliwie dużą szansą rozwoju dla regionu.

\section{LITERATURA}

[1] Abraham-Frois G., Dynamique Economique, 9 édition. Précis-Dalloz, Paris 2002.

[2] Główny Urząd Statystyczny. Departament Badań Społecznych i Warunków Życia. Informacje i opracowania statystyczne. Turystyka w 2015 roku, Zakład Wydawnictw Statystycznych, Warszawa 2016, http://www.stat.gov.pl/.

[3] Kondratowicz-Pietruszka E., Stokłosa K., Wybrane zagadnienia kinetyki procesów ekonomicznych, Wydawnictwo AE w Krakowie, Kraków 1994.

[4] Kruczek Z. Wolak G., Baza noclegowa w turystyce [w:] Obstuga ruchu turystycznego, red. Z. Kruczek, Wyd. Proksenia, Kraków 2012.

[5] Łuka P., Dynamika wzrostu liczby osób korzystających z krajowych połączeń lotniczych w Polsce w latach 2002-2005, Ekonomia i Nauki Humanistyczne, z. 16, Zeszyty Naukowe Politechniki Rzeszowskiej nr 235, Rzeszów 2007, s. 51-59. 
[6] Łuka P., Kwiatkowska-Sienkiewicz K., Kinetic analysis of quality, utility and price changes of the second-hand cars in Poland, Annals of the Ovidius University, Economic Science Series, Vol. X, Issue 1, 2010, s. 1219-1223.

[7] Łuka P., Kwiatkowska-Sienkiewicz K., Quality and utility estimation of the second-hand cars, Current trends in commodity science. Selected quality problems, Zeszyty Naukowe UE w Poznaniu nr 160, Poznań 2010, s. 144-153.

[8] Łuka P., Łuka M., Analiza działalności hotelarskiej w Polsce w latach 1994-1999. Ekonomia i Nauki Humanistyczne z. 11. Zeszyty Naukowe Politechniki Rzeszowskiej nr 201, Rzeszów 2002, s. 137-146.

[9] Stokłosa K., Krytyka wspótczesnych metod oceny i porównań dynamiki procesów ekonomicznych, Materiały Konferencji Naukowej Politechniki Radomskiej, Radom 2004.

[10] Stokłosa K., Krytyka wspótczesnych metod oceny dynamiki procesów w ekonomii $i$ zarzadzaniu, praca zbiorowa pod red. nauk. M. Trockiego i S. Gregorczyka, SGH w Warszawie, Warszawa 2006.

[11] Świstak E., Sawicka B., Świątkowska M., Baza noclegowa jako czynnik rozwoju turystyki w województwie warmińsko-mazurskim. Studia i Materiały CEPL w Rogowie, R. 15, z. 37/4/2013, s. 313-320.

[12] Urząd Statystyczny w Rzeszowie, Ośrodek Statystyki Sportu i Turystyki oraz Podkarpacki Ośrodek Badań Regionalnych, Informacje i opracowania statystyczne, Turystyka w województwie podkarpackim w latach 2014 i 2015, Rzeszów 2016, http://rzeszow. stat.gov.pl/.

\section{THE DYNAMICS OF CHANGE IN THE NUMBER OF OVERNIGHT GUESTS IN HOTELS IN SUBCARPATHIAN REGION}

The aim of the study is to analyze the dynamics of changes in the number of tourists using hotel accommodation services in Subcarpathian Region in the years 2008-2015. The empirical data from the Central Statistical Office and the Statistical Office in Rzeszow were used for the evaluation. The data on changes in the number of domestic and foreign tourists using accommodation services were analyzed in detail, using methods of estimating the dynamics of economic processes on both absolute and relative scale. Relative results give a better picture of the dynamics of changes in economic processes, as values have the same initial value of 100 percent. The attention was drawn not only to percent changes in the processes under investigation but also to the speed and acceleration of these changes. Thus, the results show the dynamics of each of the initial 100 people using hotel services in Subcarpathian Region in the years 2008-2015. Comparing the dynamics of processes for both point and continuous values, both absolute and relative, for both Polish and foreign tourists, a general upward trend has been observed for both cases, despite a slight decline in 2011-2012. It has also been noted in the researched years that the dynamics of the growth of the number of foreign tourists using hotel services is slightly greater than domestic tourists, although the total values represent a completely opposite picture. This proves the growing 
interest of foreign tourists in the Subcarpathian tourist market, despite the fact that their share in the total number is still relatively low.

Keywords: hotel management, dynamics of change, hotels, accommodation, tourism.

DOI: 10.7862/rz.2017.mmr.31

Tekst ztożono $w$ redakcji: październik 2017 r.

Przyjęto do druku: grudzień 2017 r. 
